\title{
The Impact of Myriad on the Future Development and Commercialization of DNA-Based Therapies and Diagnostics
}

\author{
Michele Wales and Eddie Cartier \\ InHouse Patent Counsel, LLC, Potomac, Maryland 20854 \\ Correspondence: mwales@inhousepatentcounsel.com
}

One of the reasons that the United States is a leader in biotechnology is its strong and reliable patent system. However, the Supreme Court's decision in Myriad potentially limits an inventor's ability to protect her DNA-based inventions. Fortunately, with creativity, there are numerous ways in which to "claim around" Myriad, enabling inventors to fully protect their diagnostic or therapeutic inventions. Thus, under a proper reading of the holding, the potential negative effect of Myriad on the progress of biotechnology would be negligible. Unfortunately, the U.S. Patent and Trademark Office has promulgated revised examination procedures in the wake of Myriad that have the potential to greatly limit the patentability of all inventions based on products found in nature and create uncertainty that will not be resolved in the near future.

\section{PATENT PROTECTION IS NECESSARY FOR BIOTECHNOLOGY}

$\mathrm{B}$ iotechnology requires intensive research and development (R\&D) efforts, and money is needed to pay for those efforts. Patents reassure investors that they will be able to recoup their investment in the event that a biotech company is able to develop a commercial product by preventing competitors from copying the new product during the life of the patent. Therefore, biotech companies, especially start-up companies, rely heavily on patent protection to support their R\&D efforts. ${ }^{1}$

${ }^{1}$ CRS Report for Congress, "Mayo v. Prometheus: Implications for Patents, Biotechnology, and Personalized Medicine" (Nov. 2012).
For example, a novel therapeutic requires in vitro and in vivo testing, manufacturing validation, and extensive clinical trials before approval by the Food and Drug Administration (FDA). All of these steps in bringing a new drug to market have been estimated to cost, on average, more than $\$ 1.2$ billion. Patents provide incentive for investors that a novel therapeutic can be protected, as copying an existing drug (i.e., making a generic version) is relatively inexpensive and easy. Moreover, there is a statutory (Hatch-Waxman) and regulatory (FDA) framework restricting how would-be generic manufacturers can enter the market-that is, by challenging (and only after defeating) the patents covering an innovator company's drug. Thus, patents are inextricably tied to drug development.

Editors: Salim Mamajiwalla and Rochelle Seide

Additional Perspectives on Intellectual Property in Molecular Medicine available at www.perspectivesinmedicine.org

Copyright (C) 2015 Cold Spring Harbor Laboratory Press; all rights reserved; doi: 10.1101/cshperspect.a020925

Cite this article as Cold Spring Harb Perspect Med 2015;5:a020925 
Additionally, trade secret protection, a viable option for the secret formula for Coca-Cola, is not an option for biotech products. At multiple points in the development of a new biotech product, whether it is a therapeutic or a diagnostic product, a company will be asked to disclose the structure of the product or the details of the assay. For example, for a therapeutic drug, the FDA requires a company to disclose the chemical structure in the package insert accompanying the sale of every therapeutic drug. Similarly, to validate a new diagnostic test, scientific journals, the FDA, and insurance carriers will all require that the assay be specifically described in order to independently evaluate and approve of the credibility of the assay. Thus, trade secret protection is generally not a viable alternative for biotech products.

In fact, investors in biotechnology stress the importance of patents. For example, venture capital (VC) firms are the primary source of funding for small biotech companies. Startups with patenting activity receive greater and more diverse VC funds. In fact, the filing of at least one patent application has been shown to increase the chance of obtaining VC funding by $97 \%$ and reduce the time for first investment by $76 \%$ (Häussler et al. 2008).

Thus, efforts by Congress, the courts, and now even the U.S. Patent and Trademark Office (USPTO) that limit the ability to obtain strong patent protection for biotech products have the potential to undermine investor confidence and lead VC firms to invest in less risky industries. It is critical for biotech companies to find ways in which to "claim around" these limitations placed upon them to create strong intellectual property portfolios even in view of these hurdles. The Supreme Court's decision in Myriad (and its broad application by the USPTO) is just one of the recent case law hurdles, and just one example of the general movement against a strong patent system that biotech companies must overcome.

\section{HISTORICALLY, MOST BIOTECH INVENTIONS WERE PATENTABLE}

The framers of the U.S. Constitution recognized the importance of patent protection when they gave Congress the power " $t \mathrm{t}$ ] o promote the Pro- gress of Science and useful Arts, by securing for limited Times to Authors and Inventors the exclusive Right to their respective Writings and Discoveries" (Article 1, Section 8). Congress defined what was patentable, or "patent-eligible," as "any new and useful process, machine, manufacture, or composition of matter, or any new and useful improvement" (35 U.S.C. \$101).

In the past, the Supreme Court has explained that Congress intended with this language that "the patent laws would be given wide scope" and to include "anything under the sun that is made by man" (Diamond v. Chakrabarty (447 U.S. 303, 308-309) (1980)). This historically broad scope was allowed because it was recognized that the claimed material must still meet the secondary hurdles of novelty and nonobviousness, as well as certain requirements intended to ensure that a patent applicant has sufficiently demonstrated possession of the invention and has disclosed enough to enable others to make and use the invention.

With this broad scope of patent-eligibility protection, the United States ushered in the era of biotechnology. Life-forms (e.g., genetically engineered "oil-eating" bacteria) were deemed patentable subject matter, along with plants and transgenic animals. The breadth of patent protection had an immediately favorable impact in the United States on industries utilizing recombinant DNA technologies.

Recent U.S. decisions, however, have substantially narrowed the scope of patentable subject matter, particularly for biotech inventions. The Supreme Court has held that although patent eligibility is broad, it is subject to important limitations. For example, laws of nature, natural phenomena, and abstract ideas (e.g., mental processes) are not patentable (Association for Molecular Pathology v. Myriad Genetics, Inc. (133 S. Ct. 2107) (2013); Mayo Collaborative Services v. Prometheus Laboratories, Inc. (132 S. Ct. 1289) (2012)).

For biotech inventions, the recent Myriad decision and the way that it is being applied by the USPTO has the potential to dramatically limit subject-matter eligibility governed under United States law by 35 U.S.C. $\$ 101$ for DNAbased inventions. 
Association for Molecular Pathology v. Myriad Genetics, Inc. (133 S. Ct. 2107) (2013)

Myriad Genetics Inc. had licensed several patents from the University of Utah, the National Institutes of Health, and several other government and academic institutions that described the precise location and sequence of the $B R C A 1$ and $B R C A 2$ genes. These patents also described certain mutations in BRCA1 and BRCA2 genes that significantly increased the risk of developing breast and ovarian cancer. In licensing these patents, Myriad then developed diagnostic tests to detect whether a patient's sample had the mutations in BRCA1 or BRCA2. In an effort to protect its business model, Myriad sued a clinical lab that was competing with Myriad's breast cancer tests.

Nearly a decade after that suit was dismissed and after Myriad brought BRCA testing into the mainstream, patients, advocacy groups, doctors, and the Association for Molecular Pathology filed suit. The district court held that the challenged claims were invalid because they covered products of nature. On appeal, this decision was partially reversed, with the federal court finding that both isolated DNA and complementary DNA (cDNA) were patentable subject matter, but affirming that the method claims were improperly directed to purely mental activity.

The decision was then appealed to the U.S. Supreme Court, which reversed the federal court's decision in part. The Supreme Court held that "a naturally occurring DNA segment is a product of nature and not patent eligible merely because it has been isolated, but that the cDNA is patent eligible because it is not naturally occurring" (Myriad at 2111). In fact, the Supreme Court believed that "Myriad did not create anything. To be sure, it found an important and useful gene, but separating that gene from its surrounding genetic material is not an act of invention" and that "groundbreaking, innovative or even brilliant discovery does not by itself satisfy" patent eligibility under 35 U.S.C. $\$ 101$ (Id. at 2117).

In reaching its decision, the Supreme Court did acknowledge that synthetic DNA (e.g., cDNA) was in fact patentable. Here, it stated:
It is also possible to create DNA synthetically through processes similarly well known in the field of genetics. One such method begins with an mRNA molecule and uses the natural bonding properties of nucleotides to create a new, synthetic DNA molecule. .. . This synthetic DNA created in the laboratory from mRNA is known as complementary DNA (cDNA) (Id. at 2112).

cDNA does not present the same obstacles to patentability as naturally occurring, isolated DNA segments.... Petitioners concede that cDNA differs from natural DNA in that "the non-coding regions have been removed." They nevertheless argue that cDNA is not patent eligible because " $[t]$ he nucleotide sequence of cDNA is dictated by nature, not by the lab technician." That may be so, but the lab technician unquestionably creates something new when cDNA is made [Id. at 2119] [internal citations removed].

Logically, DNA sequences that encode variant protein sequences, much like cDNA, would also be patentable under its decision, as variant sequences are not found in nature.

The good news is that the holding in Myriad was narrowly focused by the Supreme Court. The bad news, as discussed below, is that the USPTO has generated a guidance document in response to Myriad (and Mayo) that extends the analysis far beyond the actual holdings in those cases and greatly decreases the scope of patentable subject matter in the United States.

\section{THE APPROPRIATE IMPACT OF MYRIAD ON BIOTECHNOLOGY}

The Supreme Court affirmatively stated that non-naturally occurring nucleic acids (e.g., cDNA) and man-made variant sequences were patentable. In contrast, what was not patentable was the exact molecule extracted from nature. Because of the redundancy of the genetic code and expression codon preferences, it would have been a straightforward exercise to design a particular DNA sequence that is not found in nature but can be used to code for a human protein and still be patentable under Myriad.

However, it is unfortunate that the Supreme Court felt that it needed to make a decision on this issue at all. The Human Genome Project published multiple versions of the human ge- 
nome in 2000-2003. With a 20-year patent term, the majority of the human gene patents that were on file just prior to that publication will expire within the next $7-10$ years. In fact, many of the human gene patents that were filed in the early to mid-1990s have already expired or have been abandoned.

Currently, it takes at least 10 years from discovery to bring a new biological therapy to market. Thus, if a company has not yet started clinical trials, it is likely that any human gene patent now in force will expire before the company has progressed through clinical trials, obtained FDA approval, and entered the marketplace.

Therefore, it was not necessary to make dramatic and sweeping changes in rights that have existed for more than 30 years to "solve" a supposed problem that was close to being a nonissue because of the patent system's time limit in granting monopolies.

There was a perception that scientists needed the freedom from lawsuit to study human gene sequences. However, there is no evidence that a company or university has sued a scientist for performing purely academic research. In fact, material transfer agreements are entered into between academic researchers and companies and/or universities all the time, as shown by the numerous acknowledgments in scientific journal publications. In fact, contrary to popular perception, companies want to encourage further research on human genes so that new medical treatments can be discovered and developed to address unmet medical needs and ease patients' suffering. In addition, the cost of litigation would have far outweighed any potential recovery in damages that might be obtained from patent litigation against academic researchers. Thus, the Myriad decision was not necessary to provide academic researchers with the ability to study human gene sequences.

\section{USPTO GUIDANCE UNDER THE NEW SUPREME COURT DECISIONS}

Not unexpectedly, the same day that the decision in Myriad was announced, the USPTO provided guidance to its examiners in examin- ing DNA-based inventions. The USPTO instructed:

Examiners should now reject product claims drawn solely to naturally occurring nucleic acids or fragments thereof, whether isolated or not, as being ineligible subject matter under 35 U.S.C. $\$ 101 .^{2}$

Thus, patent claims encompassing DNA molecules merely physically extracted from a natural source were no longer valid. Although the decision in Myriad and the subsequent USPTO guidance represented a significant limitation on the ability to protect DNA-based inventions, it did provide for relatively clear law on the patentability of biotechnological inventions.

That clarity was lost on March 4, 2014, when the USPTO provided revised guidance to its examiners for the determination of which types of inventions are patent-eligible in view of the Supreme Court decisions in Myriad and Mayo: "Guidance for Determining Subject Matter Eligibility of Claims Reciting or Involving Laws of Nature, Natural Phenomena, \& Natural Products" (or Revised Guidance), which was attached to the memorandum issued on March 4, 2014, by Andrew Hirshfeld, Deputy Commissioner for Patent Examination Policy, entitled “2014 Procedure for Subject Matter Eligibility Analysis of Claims Reciting or Involving Laws of Nature/Natural Principles, Natural Phenomena, and/or Natural Products" (Cover Memo). In this guidance, the USPTO attempts to synthesize a cohesive regulation, extrapolating from the various Supreme Court decisions, in order to determine patent eligibility based on predictions about what the court might say in future cases.

Along with the Revised Guidance, the USPTO released slide sets and its internal training materials to assist the public with understanding the changed examination process. These changes were discussed at a forum hosted by the USPTO on May 9, 2014. At the forum the USPTO announced that the examination

\footnotetext{
${ }^{2}$ Supreme Court Decision in Association for Molecular Pathology v. Myriad Genetics, Inc., Memorandum Issued on June 13, 2013, by Andrew Hirshfeld, Deputy Commissioner for Patent Examination Policy.
} 
procedures would be revised yet again and sought public comment prior to the next revision. The USPTO received more than $80 \mathrm{com}$ ments regarding the Revised Guidance in response to this invitation. ${ }^{3}$ All but eight comments indicated that the Revised Guidance went far beyond the holdings of Mayo and Myriad. Three of these were from individuals, and the other five all came from organizations that had submitted briefs supporting the Association for Molecular Pathology in Myriad (either as plaintiffs or as amici).

\section{Revised Guidance Provided March 4, 2014}

The Revised Guidance document attempts to extend the holdings of Myriad and Mayo to all claims (machine, composition, manufacture, and process) "reciting or involving" so-called "judicial exceptions" (Revised Guidance at 1). These exceptions include "laws of nature/natural principles, natural phenomena, and/or natural products ..." (Id.). However, claims involving abstract ideas are to be examined for subject matter eligibility using the guidance in the Manual of Patent Examining Procedure (MPEP \$2106(II)) even if the claim also involves one of the other judicial exceptions (Revised Guidance at 3). The Revised Guidance purports to provide a new procedure to assist examiners in determining whether a claim reflects "a significant difference from what exists in nature" (patent-eligible) or whether it is drawn to "something that is naturally occurring" (patent-ineligible) (Cover Memo). This new procedure is a three-step process that invokes a factor-based analysis (not unlike the test for undue experimentation provided in In re Wands (858 F.2d 731) (Fed Cir. 1988)).

The procedure essentially checks all claims directed to statutory subject matter to see whether the claim "recite[s] or involve[s] one or more judicial exceptions" (Revised Guidance at 3). The Revised Guidance indicates that claimed subject matter that falls into this

${ }^{3}$ The guidance document and related materials as well as al submitted comments can be found at www.uspto.gov/ patents/announce/myriad-mayo.jsp. class of judicial exceptions includes, but is not limited to:

chemicals derived from natural sources (e.g., antibiotics, fats, oils, petroleum derivatives, resins, toxins, etc.); foods (e.g., fruits, grains, meats, and vegetables); metals and metallic compounds that exist in nature; minerals; natural materials (e.g., rocks, sands, soils); nucleic acids; organisms (e.g., bacteria, plants, and multicellular animals); proteins and peptides; and other substances found in or derived from nature (Id.).

Essentially, if the subject matter is derived from (or found in) nature, the claims will be examined under the Revised Guidance. And examiners are instructed that if there is any doubt whether a claim recites a judicial exception, it is to be treated as if it does.

All claims swept into this broad net are then considered patent-eligible only if the claim as a whole recites something "significantly different" than the judicial exception itself. Determination of significant difference is done by weighing the totality of a set of 12 relevant factors that weigh either toward or against eligibility.

The first two of these factors concern whether claimed subject matter is "non-naturally occurring and markedly different from what exists in nature" (Id. at 5 (emphasis in original)). In weighing these two factors, examiners are instructed to consider only whether there is a marked difference in structure between the claimed subject matter and the naturally occurring product and are reminded that not all structural differences rise to the level of a "marked difference." As an example, the Revised Guidance cites Myriad's holding that merely isolating a nucleic acid, although a structural change as a result of breaking of bonds, does not represent a marked difference in structure from its naturally occurring counterpart. Examiners are then instructed that a marked difference, even if generated solely by routine activity, weighs in favor of patent eligibility. The remaining 10 factors all concern claims that recite additional elements/steps in addition to the judicial exception and are designed to assist in weighing whether the additional elements/steps weigh in favor of or against patent eligibility. 
The Revised Guidance then illustrates the new procedure by way of several examples covering claims directed to a variety of statutory subject matter, several taken directly from $\mathrm{Su}-$ preme Court cases cited in Myriad, notably Chakrabarty and Funk Brothers Seed Co. v. Kalo Inoculant Co. (333 U.S. 127) (1948). In these examples, the USPTO makes several startling conclusions regarding subject matter patent eligibility post Myriad. First and foremost, any claim to a composition of matter that is structurally identical to the naturally occurring counterpart is patent-ineligible. This goes far beyond DNA or even other biotechnological inventions. It would invalidate claims to small-molecule therapeutics that are structurally identical to natural products as well. Under the new procedure, composition-of-matter claims directed to many important therapeutics, like digitalis or doxorubicin, would not be granted. In fact, some have even estimated that almost 50\% of all approved drugs from 1980-2010 would no longer be patentable. ${ }^{4}$

Further, a composition of matter that consists of a mixture of naturally occurring products would also be patent-ineligible even if that combination had a new functional property dramatically different from any of the component parts. The example provided in Example $\mathrm{C}$ of the Revised Guidance is gunpowder, which is described as "not markedly different from what exists in nature" (i.e., the naturally occurring saltpeter, sulfur, and charcoal of which it is comprised) even though the new explosive functional property of this mixture is most assuredly markedly different from what exists in nature. As one would expect given the examples above, Example E of the Revised Guidance concludes that a composition claim directed to a pair of primers is patent-ineligible as the primers are structurally identical to the naturally occurring genomic counterparts. Thus, only composition-of-matter claims directed to products that are structurally markedly different from

\footnotetext{
${ }^{4}$ Taken from www.managingip.com/Article/3334160/ Managing-Patents-Archive/Guest-post-Sherry-Knowles-re sponds-to-USPTO-comments-on-new-Myriad-guidelines .html.
}

natural products (analogs, mutants, hybrids, etc.) and mixtures thereof are deemed patenteligible under the Revised Guidance.

On a positive note, the Revised Guidance suggests that many method claims involving natural products are patent-eligible under the new examination procedures. For example, whereas a composition claim directed to doxorubicin would not be patent-eligible, a claim directed to a method of treating cancer by administering doxorubicin would be patent-eligible (Example B). And whereas a claim directed to a pair of primers is not patent-eligible, a claim directed to a method of amplifying target DNA using these primers would be patent-eligible (Example E). With respect to claims directed to diagnostic methods, the Revised Guidance indicates that broad claims directed to abstract ideas or natural principles are not patent-eligible. For example, a claim directed to a method of diagnosing an increased susceptibility to disease based on "comparing" the test sequence to the wild-type sequence would fail under the guidance in MPEP \$2106(II) (Example H). However, the Revised Guidance indicates that diagnostic claims that recite sufficient narrowing elements/steps can be patenteligible. For example, where a misfolded protein is associated with a disease state, a claim directed to a diagnostic method for determining whether a patient has that disease that comprises contacting a biological sample from the patient with an antibody that binds only the misfolded form and detecting that binding by flow cytometry would be patent-eligible because the additional elements amount to a practical application of the natural principle (Example F).

Thus, the new procedure promulgated by the USPTO in the Revised Guidance greatly limits the protection that can be sought for compositions of matter. These limits far exceed the holdings of Myriad or Mayo. Absent congressional legislation (which is unlikely), the Myriad decision stands. However, there appear to be effective ways to "claim around" the narrow Myriad decision. A key question when drafting claims is to ask "who made the physical molecule being claimed?" If the molecule has been 
merely extracted, then it will likely be patentineligible subject matter as a composition of matter. However, if the molecule is artificial and/or not found in nature, then the molecule will likely be patent-eligible.

\section{Public Outcry and USPTO Response}

Given the rather sweeping conclusions drawn by the USPTO in the Revised Guidance, the strong protests voiced by industry, by universities, and by practitioners were to be expected. During the Biotechnology/Chemical/Pharmaceutical (BCP) Customer Partnership meeting held on April 16, 2014, the USPTO acknowledged that the Office had received a lot of public input following the release of the Revised Guidance. ${ }^{5}$ The Office spent the entire afternoon session of the BCP meeting reviewing the Revised Guidance and attempting to "clear up" what it considered to be "misunderstandings" regarding the Revised Guidance. The USPTO noted that it would be hosting a forum on May 9, 2014, regarding the Revised Guidance to gather public input and that it would "update or modify the Guidance as needed." The tenor of the USPTO comments at the BCP meeting and at the forum on May 9 was that the Office felt confident that the Revised Guidance was properly based on principles mandated by case law. However, it acknowledged the challenge inherent in applying the principles. Early in the forum, the USPTO defended the broad interpretation of case law put forth in the Revised Guidance and the narrow focus on structural differences between claimed products and natural counterparts. ${ }^{6}$ However, by the end of the forum, the USPTO indicated that the Office "realize[s] that we have said structural differences [can establish that something is significantly different], but you can also have func-

\footnotetext{
${ }^{5}$ For a summary of the BCP meeting, see www.patentdocs .org/2014/04/uspto-tries-to-address-public-misunderstan dings-regarding-myriad-mayo-guidance.html.

${ }^{6}$ For a summary of the USPTO commentary provided during the forum, see www.patentdocs.org/2014/05/usptoholds-forum-on-subject-matter-eligibility-part-i.html.
}

tional differences." 7 The USPTO also acknowledged that it should have sought public input prior to issuing the Revised Guidance. ${ }^{8}$ The Office concluded the forum by inviting written comments on the Revised Guidance.

There were more than 80 comments filed in response to the USPTO invitation, and the vast majority of comments were overwhelmingly negative. There were many valid issues raised regarding the conclusions in the Revised Guidance. As one example, many raised the obvious point that the Revised Guidance ignored the explicit limitations the Supreme Court placed on its holdings in Myriad and Mayo and went well beyond the decisions in those cases. Additionally, many also raised the issue that the current Revised Guidance would now hold as patent-ineligible many claims directed to composition of matter that have long been granted by the USPTO. This, they indicate, is a result of a number of errors in the USPTO's analysis.

First, the USPTO used very broad language to sweep in all claims that merely recite or involve a judicial exception, rather than just those that are directed to a judicial exception. Second, the USPTO focused on structural differences between the claimed product and the naturally occurring products and ignored the relevant functional differences that often support a finding of patent eligibility.

In addition to the substantive issues raised as just discussed, many made policy arguments against the interpretations put forth in the Revised Guidance. For example, several indicated that the new procedures were inconsistent with the international treaty obligations of the United States. In particular, the definition of patent eligibility in the Revised Guidance is not consistent with the definition provided in the Agreement on Trade-Related Aspects of Intellectual Property Rights (TRIPs). ${ }^{9}$

\footnotetext{
${ }^{7}$ See www.patentdocs.org/2014/05/uspto-holds-forum-onsubject-matter-eligibility-part-iv.html.

${ }^{8}$ See www.patentdocs.org/2014/06/guest-post-uspto-publicforum-on-patent-guidance-my-thoughts-as-a-speaker-andattendee.html.

${ }^{9}$ See the Uruguay Round Agreements Act, Pub. L. No. 103465, 108 Stat. 4809 (1994).
} 
In a series of meetings held after the comment period, the USPTO has indicated that it will be revising the guidance documents in view of the extensive public feedback received. ${ }^{10}$ The USPTO had initially that the new guidance documents would be issued by late October or early November 2014. However, during the November 11, 2014 BIO meeting, the USPTO would only confirm that the revised guidance would issue "very soon." Unfortunately, the USPTO indicated that it does not intend to limit the guidance to DNA only because the Office feels that the decision in Myriad "does not stand alone." ${ }^{11}$ However, the USPTO did finally acknowledge that the Office had "cast too broad a net" in the Revised Guidance. Among the expected changes, the new guidance will focus only on claims that are "directed" to a judicial exception rather than to claims that merely "involve" a judicial exception. With respect to determining whether a claimed product is different from the natural counterpart, the USPTO indicated that the term "significantly different" will be eliminated in the new guidance materials, as many had suggested that it represented an improper new legal standard not provided by the courts. Further, the Office indicated that it was wrong to limit the query to only structural differences. The new guidance will consider functional differences and "other things" in this analysis. The Office will also be eliminating the complicated 12-element factor-based analysis from the new guidance materials as too complex. Finally, the materials will incorporate many new examples to provide additional clarity.

It remains to be seen whether the USPTO will revise the guidance documents to comport

\footnotetext{
${ }^{10}$ These changes were discussed by the USPTO at the BCP meeting held September 17, 2014, at the Biotechnology Industry Organization (BIO) IP \& Diagnostics Symposium held September 26, 2014, in Alexandria, VA, and at the BIO Intellectual Property Councils Committee (IPCC) Full Conference held November 11, 2014, in Nashville, TN.

${ }^{11}$ For a summary of the comments made at the BIO Symposium, see www.patentdocs.org/2014/10/uspto-outlineschanges-to-myriad-mayo-guidance-at-bio-symposium .html
}

with the actual holdings in Myriad and Mayo and thus limit the products that are deemed patent-ineligible to those mentioned by the $\mathrm{Su}$ preme Court. If past Office behavior is any guide, it seems clear that the guidance materials will have to be challenged and subjected to judicial review before the USPTO will relent. Thus, it does not appear that there will be clarity any time soon for inventors regarding the patent eligibility of products of natural origin.

\section{Claim Drafting}

The following are some examples of ways in which to claim compositions of matter based on the Myriad decision and the USPTO's Revised Guidance. Obviously, method-of-diagnosis and/or method-of-treatment claims could also be used to protect the compositions, assuming, of course, that the method claims are not a problem under Mayo (e.g., not claiming a law of nature). However, most patentees want to protect their invention with composition-ofmatter claims as method claims are often easily designed around, so finding ways to claim around Myriad is important in protecting biotech inventions.

\section{Diagnostic Claims}

Composition-of-matter claims attempting to protect the detection of a single gene mutation may be difficult going forward in view of $M y r-$ iad. Typically, to detect a single gene mutation, primers that flank the mutation are designed to amplify the region of interest. Therefore, claims directed to those primers are often pursued.

However, the Supreme Court in Myriad raised (but at most left for another day) the question of patent eligibility for polynucleotides comprising short stretches of DNA:

[V]ery short series of DNA may have no intervening introns to remove when creating cDNA. In that situation, a short strand of cDNA may be indistinguishable from natural DNA [Myriad at 2119] [emphasis added].

Therefore, claims directed to polynucleotides comprising short stretches of DNA sequence 
are likely unpatentable. For example, the following claims would no longer be patent-eligible: ${ }^{12}$

1. a synthetic polynucleotide comprising 15 nucleotides of SEQ ID NO:G;

2. a primer comprising 15 nucleotides of SEQ ID NO:G.

However, there are ways to protect primers as compositions of matter. First, if the diagnostic method relies on a tag or adapter molecule fused to the primer for detection, then examples of patent-eligible claims could recite:

1. a polynucleotide comprising SEQ ID NO:P fused to a flag (or an adapter or a marker, etc.);

2. a pair of single-stranded DNA primers for determining the nucleotide sequence of Gene $\mathrm{X}$ by a polymerase chain reaction, the sequence of said primers being derived from human chromosome $\mathrm{Y}$, wherein the use of said primers in a polymerase chain reaction results in the synthesis of DNA having all or part of the sequence of Gene X.

Clearly, to successfully claim primers or genomic sequences used to detect single-gene mutations, the composition-of-matter claim must recite elements that are not found in nature; it is no longer sufficient to claim just a polynucleotide comprising a short stretch of nucleotides.

Additionally, diagnostic tests are moving away from single-gene tests and instead are focusing on more complex, multiple-marker tests often used to provide risk analysis. In these assays, the expression pattern of a combination of multiple, different genes along with an algorithm used to predict prognosis, for example, are used. Panels of biomarkers and informational models, rather than a single gene, are

\footnotetext{
${ }^{12}$ All of the following exemplified claims will use the same key. An amino acid sequence will be represented as "SEQ ID NO:A," a genomic polynucleotide sequence will be represented as "SEQ ID NO:G," a cDNA polynucleotide sequence will be represented as "SEQ ID NO:C," and a short primer sequence will be represented as "SEQ ID NO:P."
}

combined to provide mathematical signatures used to predict risk of progression of disease.

Drafting composition-of-matter claims to overcome Myriad when protecting multiplemarker tests is more straightforward, as the selection and combination of the specific genes is not found in nature. For example, if one claimed the following method for a multiple-marker diagnostic test:

A method of classifying disease $\mathrm{X}$ comprising:

1. measuring in a sample from a patient the expression of a plurality of test genes, wherein said test genes are chosen from the group consisting of [insert list of genes];

2. calculating a test score for said sample based at least in part on the expression of said test genes measured in (1);

3. classifying said patient as having a poor prognosis based at least in part on said test score exceeding a reference score.

then examples of composition-of-matter claims that could be used to protect this method could include:

1. a kit comprising primers that bind a plurality of test genes, wherein said test genes are chosen from the group consisting of [insert list of genes];

2. a 96-well plate comprising primers that bind a plurality of test genes, wherein said test genes are chosen from the group consisting of [insert list of genes].

Thus, even under Myriad and the USPTO's Revised Guidance, protecting diagnostic methods with composition-of-matter claims is still possible.

\section{DNA-Based Therapies}

Gene Therapy. Any therapy that uses an artificial variant of a naturally derived DNA sequence remains patent-eligible even after $\mathrm{Myr}$ $\mathrm{iad}$. For example, using gene therapy to administer to a patient a cDNA sequence (SEQ 
ID NO:C) contained in a viral vector could be claimed in a number of different ways. For example, polynucleotide claims protecting gene therapy compositions could include:

1. a cDNA (or polynucleotide) sequence comprising SEQ ID NO:C;

2. a vector comprising SEQ ID NO:C;

3. a polynucleotide sequence comprising SEQ ID NO:C fused to a heterologous promoter.

This same claim structure could also be used if the polynucleotide sequence encoded a variant protein sequence not found in nature.

It is a bit more difficult if a patient is being administered a polynucleotide sequence found in nature (such as a gene sequence that lacks introns, and therefore the cDNA and genomic sequence is identical). In this situation, the vector and/or the heterologous promoter claims described above are likely the best way to protect this type of invention as composition-of-matter claims.

Of course, methods of treatment claims are still available to protect gene therapy inventions regardless of the type of polynucleotide sequence used.

Therapeutic Proteins and Antibodies. Therapeutic proteins were not considered in Myriad, and therefore under a proper reading of the holding in that case remain patent-eligible even if the amino acid sequence used to treat patients is identical to the naturally derived protein. However, as discussed above, the USPTO has extended Myriad and Mayo well beyond the holdings in those cases. Under the USPTO's Revised Guidance, the patentability of many products derived from nature (not just in biotechnology) is now in question.

Under a proper reading of Myriad, claiming a wild-type or variant protein sequence (SEQ ID NO:A) is a straightforward exercise. For example, the claim would recite:

1. a polypeptide comprising SEQ ID NO:A.

However, under the USPTO's Revised Guidance, this claim would not be patent-eligible. Instead, changes in glycosylation patterns from what is found in nature, for example, may need to be recited in order for the claim to be patenteligible. If the protein sequence (SEQ ID NO:A) is encoded by a gene having introns, the cDNA sequence can be used to encode the protein in manufacturing. In this situation, claims could recite:

1. a cDNA sequence encoding the polypeptide of SEQ ID NO:A;

2. a microbial organism comprising a cDNA sequence encoding the polypeptide of SEQ ID NO:A.

Therapeutic antibodies should also not have any issues under Myriad. Therapeutic antibodies are typically not found in nature but are instead synthetically designed and produced. Therefore, the amino acid sequence of the antibody as well as all polynucleotides that encode the antibody should be patent-eligible.

Newly Discovered Genes Lacking Introns. It is unclear whether the Supreme Court considered how its holding in Myriad would affect the patentability of newly discovered genes that lack introns. For example, are newly discovered genes found in microorganisms (which lack introns) protectable by patents? Every year, scientists find new bacteria and other microorganisms often in remote areas in the world. What if one of these microorganisms has a gene that provides a new energy source, or amplifies food production, or provides insect resistance to food sources? In this situation, the "cDNA" would be identical to the genomic sequence. Under the USPTO's Revised Guidance, this DNA molecule would not be patent-eligible subject matter no matter how " $\mathrm{g}]$ roundbreaking, innovative or even brilliant" the discovery is.

One way to protect these new inventions is to ensure that the application is written with language that will allow one to disclaim the specific polynucleotide sequence found in nature, while claiming all other polynucleotide sequences. For example, the claim could recite:

1. a polynucleotide sequence encoding the amino acid sequence of SEQ ID NO:A, wherein the polynucleotide sequence is not SEQ ID NO:G. 
In this situation, SEQ ID NO:G would need to be explicitly described in the specification at the time of filing in order to include it in the claim as a disclaimer. The problem with this option is that if a new polymorphic polynucleotide sequence that also encodes SEQ ID NO:A is later discovered in nature, there would not be proper support in the specification to disclaim the variant sequence. One way to overcome this potential problem is for the patent drafter to define "a polynucleotide sequence" as one that does not encompass the exact nucleotide sequence found in nature.

\section{CLAIM DRAFTING DOES NOT END WITH MYRIAD}

\section{Claims Need to Be Drafted to Also Avoid Mayo Rejections}

In Mayo Collaborative Services v. Prometheus Laboratories, Inc. (132 S. Ct. 1289) (2012), the U.S. Supreme Court found that claims reciting methods for detecting a natural correlation between a metabolite and the likelihood of responding to a drug, without "more," are not patentable.

In Mayo, Prometheus licensed a patented method for determining the ideal dosage of thiopurine drugs in treating autoimmune diseases. The inventors discovered that the drug was most effective when the concentration of a particular metabolite in a blood sample fell within a narrow window. The patent recited method claims using a fairly typical series of steps:

1. Administer the drug.

2. Determine the level of the metabolite.

3. Increase or decrease the next dose depending on whether the level of metabolite falls within a standard.

Importantly for the Supreme Court, the claim did not require the actual administration of the next dose; rather, the "increasing" or "decreasing" step was only "indicated."13

\footnotetext{
${ }^{13}$ Prometheus' claim 1 is repeated below in its entirety (emphasis added): 1. A method of optimizing therapeutic efficacy for treatment of an immune-mediated gastrointestinal disorder, comprising: (a) administering a drug providing
}

The Supreme Court found this claim unpatentable because the relationship between the metabolite concentration and the optimized dosage was a "law of nature." It reasoned that more was necessary to transform the relationship of this natural law into a patent-eligible subject matter.

The Supreme Court held that for a process claim to cover a patentable application of a natural law, it must "contain other elements or a combination of elements, sometimes referred to as an 'inventive concept,' sufficient to ensure that the patent in practice amounts to significantly more than a patent upon the natural law itself" (Mayo at 1294). Biological process claims fail this requirement if, apart from the "natural law," they contain nothing more than "well-understood, routine, conventional activity previously engaged in by researchers in the field" (Id.). In fact, the Supreme Court emphasized that "simply appending conventional steps, specified at a high level of generality, to laws of nature, natural phenomena, and abstract ideas cannot make those laws, phenomena, and ideas patentable" (Id. at 1300; see also id. at 1298) ("Purely conventional or obvious pre-solution activity is normally not sufficient to transform an unpatentable law of nature into a patent-eligible application of such a law.") (internal quotation marks omitted).

Thus, the Supreme Court in Mayo held that claims reciting a relationship between a drug concentration and the optimized dosage was patent-ineligible as merely describing a law of nature and needed something more in the claim, beyond conventional, well-understood, or routine steps, to transform the claim into patent-eligible subject matter.

6-thioguanine to a subject having said immune-mediated gastrointestinal disorder; and (b) determining the level of 6-thioguanine in said subject having said immune-mediated gastrointestinal disorder, wherein the level of 6-thioguanine less than about $230 \mathrm{pmol}$ per $8 \times 10^{8}$ red blood cells indicates a need to increase the amount of said drug subsequently administered to said subject and wherein the level of 6-thioguanine greater than about $400 \mathrm{pmol}$ per $8 \times 10^{8}$ red blood cells indicates a need to decrease the amount of said drug subsequently administered to said subject. 
M. Wales and E. Cartier

\section{Claims Need to Be Drafted to Avoid Prior Art}

Probably the most daunting hurdle to overcome for a human DNA-based invention is not Myriad or Mayo, but instead the prior art. The human genome was published in the early 2000s. Therefore, any claims contained in applications filed after this publication that are broad enough to encompass a nucleotide sequence found in nature will be not patentable, as they will lack novelty. Specifically, the following claims would all be unpatentable if a single example of a polynucleotide exists in a publication prior to the application filing date:

1. a polynucleotide comprising SEQ ID NO:G;

2. a polynucleotide comprising at least $30 \mathrm{nu}-$ cleotides of SEQ ID NO:G;

3. a polynucleotide $80 \%$ identical to SEQ ID NO:G.

Thus, a prior art publication of a single example of the claimed sequence has the ability to prevent the patenting of broad classes of DNA sequences.

\section{Claims Need to Be Drafted to Avoid Divided Infringement (If Possible)}

To infringe a claim, the accused infringer needs to practice each and every element of the claim. As a general rule, only one party can perform all steps of a patented method to directly infringe. However, two parties' actions can be combined to infringe a claim so long as a "controlling relationship" such as an "agency-principal relationship" exists among the multiple parties. (See McKesson Technologies, Inc. v. Epic Systems Corp. (No. 2010-1291, slip op. 7-8); Akamai Technologies, Inc. v. Limelight Networks, Inc. (629 F.3d 1311, 1318-1319) (Fed. Cir. 2010); Golden Hour Data Systems, Inc. v. emsCharts, Inc. (614 F.3d 1367, 1380-1381) (Fed. Cir. 2010); BMC Research, Inc. v. Paymentech, L.P. (498 F.3d 1373, 1381-1382) (Fed. Cir. 2007); Muniauction, Inc. v. Thomson Corp. (532 F.3d 1318, 1330) (Fed. Cir. 2008); and Limelight Networks, Inc. v. Akamai Technologies, Inc. (134 S. Ct. 2111, 2117) (2014).)
The problem is that courts have been reluctant to find the existence of a "controlling relationship" even when the defendants have formed a strategic partnership, integrated the functions of their software programs and combined their procedures into one single system, and collaborated to practice every limitation of the method claims at issue (Golden Hour (614 F.3d at 1371); (Id. at 1382-1383) (Newman, J., dissenting)).

Typically, diagnostic patent claims are method claims that contain a step of detecting a molecular marker and a separate step of correlating the detected molecular marker with disease characteristics or drug response. These two steps are often divided between separate parties. $^{14}$

Take, for example, Prometheus' claim in Mayo (see footnote 13). In commercial settings, the "administering" step and the "indicating" step are typically performed by a physician, whereas the "determining" step is performed by a diagnostic test provider. Thus, a diagnostic testing laboratory will market a test to a physician, causing the physician to order the test (the "determining" step). The lab then conducts the "determining" step and guides the physician to correlate the result of the "determining" step with a specific disease and to take appropriate further actions (e.g., "administering" drugs) according to the test result. However, neither the lab nor the physician will infringe Prometheus' claim because there is no formal agency relationship between the test provider and the physician. (See, generally, McKesson (No. 20101291); Akamai (629 F.3d 1311); Golden Hour (614 F.3d 1367); Muniauction (532 F.3d 1318); BMC Research (498 F.3d 1373); Limelight (134 S. Ct. 2111); and Global Patent Holdings, LLC v. Panthers BRHC LLC (586 F. Supp. 2d 1331) (S.D. Fla. 2008), (affirmed, 318 F. App'x 908) (Fed. Cir. 2009).) And without an underlying infringement, there can be no direct

\footnotetext{
${ }^{14}$ Warren WL, Fang L, "Biotechnology patent validity in jeopardy," Genetic Engineering News: Legal Affairs (Oct 1, 2010, Vol. 30, No. 17) (available at www.genengnews.com/ gen-articles/biotechnology-patent-validity-in-jeopardy/ $3421 /)$.
} 
Impact of Myriad

or indirect liability (McKesson (No. 2010-1291, slip op. 8-9)).

Thus, in an effort to overcome Mayo, a patentee will try to add limitations to the claim to transform the claim into something more than just a recitation of a law of nature. However, care must be taken if these limitations divide infringement between two different individuals lacking control over one another.

The result can become an impossible dilemma for those seeking to protect their expensive and valuable inventions: either languish at the patent office trying in vain to get claims that do not explicitly recite a laboratory analysis step, or include such a step and receive a worthless patent claim that can be easily infringed without fear of liability because of the current joint infringement decisions. In effect, the $\mathrm{Su}-$ preme Court has "remove[d] [personalized medicine inventions] from the purview of the patent system [...] as a matter of law" (McKesson, No. 2010-1291, slip op. 5 (Newman, J., dissenting)).

\section{CONCLUSION}

Whether a company's focus is diagnostic or therapeutic, biotech companies rely on a strong and predictable patent system. With the recent $\mathrm{Su}$ preme Court case Myriad, it may appear that biotech companies will have difficulty protecting gene-based inventions. However, under a proper reading of Myriad, that is not the case, as there are many different ways in which to "claim around" Myriad, allowing companies and universities to fully protect their DNA-based inventions. Unfortunately, the issue for biotech companies is not the holding of Myriad. Instead, it is the extensive and improper changes to patent eligibility promulgated by the USPTO in its Revised Guidance that warrants the greatest concern.

\section{REFERENCE}

Häussler C, Harhoff D, Müller E. 2008. To be financed or not: The role of patents for venture capital financing. CEPR Discussion Paper Series 7115. ZEW-Centre for Economic Policy Research, Munich, Germany. 


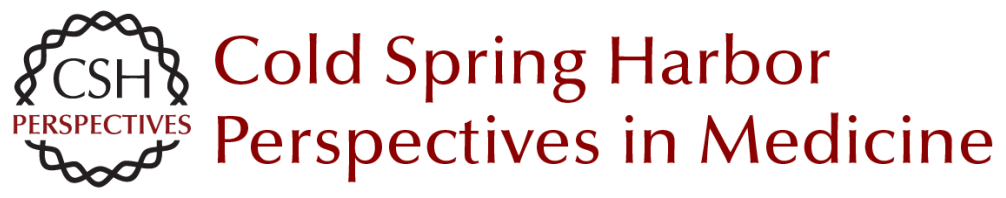

\title{
The Impact of Myriad on the Future Development and Commercialization of DNA-Based Therapies and Diagnostics
}

\author{
Michele Wales and Eddie Cartier
}

Cold Spring Harb Perspect Med 2015; doi: 10.1101/cshperspect.a020925 originally published online September 3, 2015

\section{Subject Collection Intellectual Property in Molecular Medicine}

Patentability of Stem Cells in the United States Sarah E. Fendrick and Donald L. Zuhn, Jr.

Inventorship and Authorship

Antoinette F. Konski and Linda X. Wu

The Patentability of Stem Cells in Australia Jenny Petering and Prue Cowin

Impact of America Invents Act on Biotech

Intellectual Property

Amanda Murphy, Michael Stramiello, Jonathan Stroud, et al.

Introduction to Intellectual Property: A U.S.

Perspective Amanda Murphy, Michael Stramiello, Stacy Lewis, et al.

The Role of Regulatory Agencies and Intellectual Property: Part I Kevin E. Noonan

Canada's Patented Medicines (Notice of Compliance) Proceedings and Intellectual Property Henry Bian and Conor McCourt

Patentability of Genes: A European Union Perspective Paul Cole
The Impact of Myriad on the Future Development and Commercialization of DNA-Based Therapies and Diagnostics

Michele Wales and Eddie Cartier

Protecting Traditional Knowledge Related to

Biological Resources: Is Scientific Research

Going to Become More Bureaucratized?

Prashant Reddy and Malathi Lakshmikumaran

Protecting Trade Secrets in Canada Noel Courage and Janice Calzavara

Inherent Anticipation in the Pharmaceutical and

Biotechnology Industries

Michael Goldman, Georgia Evans and Andrew Zappia

The Role of Regulatory Agencies and Intellectual

Property: Part II Kevin E. Noonan

Baseball Bats and Chocolate Chip Cookies: The Judicial Treatment of DNA in the Myriad Genetics Litigation lan Binnie and Vanessa Park-Thompson

The Impact of Myriad and Mayo: Will

Advancements in the Biological Sciences Be

Spurred or Disincentivized? (Or Was Biotech

Patenting Not Complicated Enough?) Jennifer Gordon

Trade Secrets in Life Science and Pharmaceutical Companies

Tara Nealey, Ronald M. Daignault and Yu Cai

For additional articles in this collection, see http://perspectivesinmedicine.cshlp.org/cgi/collection/ 